\title{
Vertical Asymmetric Price Volatility Transmission of Egyptian Potatoes
}

Fadi abdelradi,

Khaled Abdou

Department of Agricultural economics, Faculty of Agriculture, Cairo University

\begin{abstract}
Egyptian potatoes are considered a major agricultural crop for local consumption, processing and exports. This paper aims at shedding light on the vertical asymmetric price volatility transmission along the Potatoes supply chain between the wholesale and retail levels. We use asymmetric BEKK-MGARCH model to evaluate volatility spillovers. Empirical results confirm that there is a long-run relationship between the two prices, and the equilibrium parity is maintained by the retail price. Additionally, not only prices levels dynamics are found to be important but also asymmetric volatility spillovers between wholesale and consumer prices are also found to be relevant.
\end{abstract}

Keywords: price volatility, multivariate GARCH, Potatoes, asymmetry

\section{Introduction}

A great deal of growth potential in the agricultural sector depends on food prices (27). It is therefore relevant to understand the dynamics of price behavior in order to design adequate policies to mitigate the impacts of price shifts (6). Food prices fluctuations are one of the major issues affecting food security. It can further involve substantial social and economic consequences that are specially felt in developing countries, where the population spends most of its income on food, and thus suffers substantially from food price increases. Hence, at the economic level, food price volatility can have large impacts on farmers, market participants and consumers (30). As a net food importer, Egypt is largely vulnerable to international food price fluctuations where a succession of events at the turn of the century has worsened poverty and food security in Egypt. These include the avian influenza in 2006, the food, fuel and financial crises of 2006-2009, continued increase of food prices in 2010 and the political instability due to the civil revolution (16).

The analysis of vertical price transmission provides a picture of the overall functioning of the market (12). Understanding the extent and speed with which prices adjust to market shocks help forecasting prices and diagnose poorly functioning markets. Price transmission analyses have boomed in the agricultural economics literature and has paid substantial attention to investigate 
the presence of nonlinearities in price levels dynamics. Nonlinear price behavior has been traditionally attributed to high transaction costs, adjustment costs and concerns regarding concentration and imperfect competition in the food chain. However, other explanations for nonlinear price links based on product storage and perishability, or influence of price support policies, are possible. Drivers that cause asymmetric behavior in food prices levels are as well found to be a source asymmetry in volatility spillovers (3).

The aim of this paper is to shed light on the vertical price volatility transmission along the Egyptian potato supply chain, one of the top ten crops produced in Egypt. The potatoes industry is chosen as a case study because it is one of the most important crops grown in Egypt for local consumption, exports and processing. Potatoes are also considered as a cash crop for small farmers and yet still have limited returns due to poor seed quality and expensive fertilizers. The potatoes industry is considered one of the agricultural subsectors with a relevant concentration and vertical integration. As a result of such vertical links and market power is this sub-sector, it is reasonable to assume the presence of asymmetric price volatility spillovers.

The contribution of this work is twofold: first, it focuses on the Egyptian potatoes market. While a rich empirical literature has assessed price linkages along the food market chains in the United States (US) and the European Union (EU) countries (see i.e. (10) and (24)), other parts of the world including African countries have received less research (3). Lack of food price data in developing countries underlies the scarcity of studies on price behavior in these countries. A few exceptions to this dearth of studies on price behavior in developing economies $(1,14,31)$. Second, in contrasts to the dominant literature, we not only model prices levels, but also model volatility spillovers. While a few attempts to model volatility spillovers in the food literature have been published, our work is the first in explicitly allowing for asymmetries.

The remainder of this paper is organized as follows. Section 2 presents a review of the literature assessing nonlinear price behavior in food markets. Section 3 describes the potatoes market in Egypt. Section 4 presents the methodological approach: the MGARCH model with asymmetries. Section 5 reports and analyzes the empirical results. Section 6 presents the concluding remarks and a summary of the research results.

\section{Previous Literature}

Previous research has found ample evidence of nonlinear behavior among different levels of the food supply chain $(10,24)$. As a result, asymmetric price 
volatility spillovers should also be studied. In the following lines, we focus on vertical price links studies in the developing economies, to then review some articles assessing price volatility interactions. Mkhabela and Nyhodo (23) investigated producer-retail price transmission behavior of the poultry industry for the study period 2000 to 2010 in South Africa using a Houck and Error Correction Model. Results showed that farm-retail price transmission was found to be symmetric using both the Houck and ECM methods suggesting that changes in farm prices causes a similar change in the retail price of the poultry market in South African. Hassouneh et al. (14) studied the effect of avian influenza on the Egyptian poultry sector for the study period January 2003 to December 2006 in Egypt using a bivariate smooth transition VECM. Results showed that adjustments to deviations from market equilibrium depend on the magnitude of the avian influenza crises. Additionally, results showed that during crisis retailers exert market power to increase their marketing margin and wholesale margins start to decline.

Mofya-Mukuka and Abdulai (25) studied the effect of policy reforms on price transmission between world and domestic prices of coffee in Zambia and Tanzania for the study period of January 1986 to September 2008 adopting a momentum threshold co-integration and error correction models using monthly data from January 1988 to September 2008. Results showed that the presence of asymmetric price transmission between the domestic markets in Zambia and Tanzania and the world market. In Zambia, producer prices tend to respond more quickly to decreases than increases changes in world market prices, and this speed increased after the policy reforms. In Tanzania, results showed that producer prices generally respond quicker to increases than decreases to changes in world market prices over the entire period. Baquedano and liefert (4) studied the response of wheat, rice, maize and sorghum commodities prices in developing countries to international market prices and exchange rates employing co-integration analysis for the study period within the 2000s. Specifically, the authors estimate a single equation error correction model to study the effect of the exchange rates and international markets prices on domestic prices for 60 commodity pairing. Results indicate that consumer's markets are co-integrated with the international prices; however, the speed of transmission of the international prices and the exchange rate to the domestic markets is slow.

Ahmed and Serra (1) studied the correlation dependence using copula functions in the Millet supply chain in Niger for the study period January 1990 to December 2010. Results showed that positive link between producer and 
consumer prices becomes stronger as the marketing channels gets closer. Additionally, results showed evidence of asymmetric behavior for extreme market events where prices tend to increase than to decrease. Alhashim and Saghaian (2) studied the link between the wholesale and the retail markets for six vegetable products (tomatoes, potatoes, cucumber, squash, onion and garlic) in Saudi Arabia for the study period 1999 to December 2012. An error correction model is used to assess asymmetric price transmission for monthly data for the period of January 1999 to December 2012. Results indicate that price transmission is symmetric in the tomatoes, potatoes, and garlic markets while in the onion market prices are asymmetrically transmitted.

Studies investigating vertical food price volatility transmission in developing countries are very scarce and include; Minot (21) analyzed the prices transmission from world grain markets to 60 Sub-Sahara African markets, the finding showed a significant long-term relationship in only 13 out of the 62 prices. He also found that rice prices are more linked to world markets than are maize prices, probably because most African countries are close to selfsufficient in maize but import a large amounts of their rice requirements. Minot (22) studied food price volatility trends of African staple food prices for the study period January 1980 to march 2011 using unconditional volatility measures and univariate (GARCH) model. Results showed no evidence of increased price volatility; furthermore, price volatility is lower in processed and tradable food compared with non-tradable food. Uchezuba et al. (31) studied asymmetric price and volatility spillover in the broiler value chain using monthly data from January 2000 to August 2008 for farm and retail prices in South African broiler market using exponential generalized autoregressive conditional heteroskedasticity (EGARCH) and allowing for asymmetry. Results suggests a statistically significant asymmetric volatility spillovers effects from the farm to retail level of the value chain. Kornher and Kalkuhl (18) examined the drivers of food price volatilities in 53 developing countries based on economic, agricultural and political factors influencing domestic price volatility using panel data estimation for maize, rice sorghum, wheat and millet for the time between 2000 and 2012. The findings suggest that market fundamentals and international price volatility plays a major role in affecting domestic price. Additionally, improved market functionality and reducing transaction costs can help stabilizing prices.

\section{Potatoes market in Egypt}

Egypt is a major Potatoes producing country in Africa. In 2012, Egyptian potatoes production reached 4.7 million Metric Tons (MT), representing 16\% of 
total African Potatoes production, while the cultivated area reached 0.17 million hectares representing $8 \%$ of total potatoes cultivated area in Africa (11). In 2011, Potatoes local consumption has increased with 140 thousand MT to reach 2.75 million MT, which accounts for $73 \%$ of the total supply, compared with 2.61 million MT in 2010 (11). In terms of trade, in 2011, potatoes were considered the third most exported crop after oranges and dairy products, representing 0.85 million MT. The largest importer of Egyptian potatoes is Russia with a demand of $50 \%$ of exports, then Greece, Ukraine and Italy, respectively (32).

Potatoes production in Egypt is mainly located along the river Nile specially in the delta region where over 100 thousand small farmers are located with farm holding less than 5 acres for local consumption. Large agribusinesses that are located in the new valley of the western desert with cultivated areas reaching 5000 acres each dedicated for exports and processing (33). Egypt is totally depends on imported potatoes seeds that are disease resistant which represent around $60 \%$ of the total farm cost per acre. Only few importers controlling the potatoes seeds market and they charge high prices to local farmers which force them to resort to other low quality varieties that are less productive and relatively cheap. Prices asymmetries are likely to occur due to market power, together with adjustment costs where quantities and prices of inputs and outputs change during the turbulent political and economic conditions of the Egyptian revolution (33). Two marketing channels for potatoes, the first is through wholesalers where the majority of the small and medium size farmers receive production loans from these wholesalers, and are required to sell at least a part of their crop to them. The output is distributed into the four major wholesale markets in major cities. The second marketing channel is exporters and processors that buy directly from farmers through forward contracts or at harvest.

\section{Methodology}

According to (26) most price time-series data have common characteristics that need to be considered when conducting econometric analysis. Three of these characteristics are considered in this research. First, prices of related markets can share a tendency to co-move; such co-movement can be a result from the existence of an equilibrium relationship between individual price series and is known as co-integration. Second, commodity price time series usually have a unit root. Third, commodity prices usually exhibit volatility that tends to change over time and to display a clustering behavior. This property implies that periods of high volatility are followed by periods of high volatility and vice versa 
GARCH models have been devised to capture such volatility behavior, that express current volatility as a function of lagged volatilities and past market shocks. GARCH models are usually composed of two sub-models. The conditional mean that captures prices in levels and the conditional volatility that represents price volatility patterns. The conditional mean and variance models in this paper are estimated in one step using Maximum Likelihood (ML). The conditional mean is specified as a VECM, which characterizes both short-run and long-run price dynamics of non-stationary and co-integrated data (equation 1). The conditional variance model follows the specification of Baba-EngleKraft-Kroner (BEKK) model defined according to (8), but allows for asymmetry as presented in (equation 2). While the multivariate BEKK-GARCH model is an improvement over other more restrictive specifications, it is unable to capture asymmetric volatility patterns. We adopt asymmetric specification of the multivariate BEKK-GARCH (19).

$$
\begin{aligned}
& \Delta \mathrm{P}_{\mathrm{t}}=\alpha_{\mathrm{p}} \varepsilon_{\mathrm{t}-1}+\sum_{\mathrm{i}=1}^{1} \beta_{1} \Delta \mathrm{P}_{\mathrm{t}-\mathrm{i}}+\mathrm{u}_{\mathrm{t}} \\
& \mathrm{H}_{\mathrm{t}}=\mathrm{CC}^{\prime}+\mathrm{A}^{\prime} \mathrm{u}_{\mathrm{t}-1} \mathrm{u}_{\mathrm{t}-1}^{\prime} \mathrm{A}+\mathrm{B}^{\prime} \mathrm{H}_{\mathrm{t}-1} \mathrm{~B}+\mathrm{D}^{\prime} v_{t-1} v_{t-1}^{\prime} \mathrm{D} \\
& l_{t}=-\left(\frac{1}{2}\right) \sum_{\mathrm{t}=\mathrm{t}+1}^{\mathrm{t}} \log \left|\mathrm{H}_{t}\right|-\left(\frac{1}{2}\right) \sum_{\mathrm{t}=\mathrm{t}+1}^{\mathrm{t}} e_{t}^{\prime} \mathrm{H}_{t}^{-1} \mathrm{e}_{t}
\end{aligned}
$$

where $\Delta$ represents the first differences operator, $P_{t}$ and $P_{t-i}$ are, respectively, $n$-dimensional vectors of the current and lagged prices. The term $\varepsilon_{\mathrm{t}-1}$ is the lagged residual from the long-run (co-integration) relationship, and $\alpha_{\mathrm{p}}$ is an $n$-dimensional vector containing parameters that measure the speed at which a variable adjusts to disequilibrium from the long-run equilibrium relationship. Matrix $\beta_{\mathrm{i}}$ represents the short-run price dynamics. Vector $u_{t}$ contains $n$ white noise residuals that may be correlated with each other. A, B, C and $\mathrm{D}$ are $(2 \times 2)$ parameter matrices that capture the volatility process. Matrix A represents the ARCH effect, i.e., the impact of market innovations on the volatility process. Matrix B contains the GARCH effect, i.e., the impact past volatility on current volatility. The $\mathrm{C}$ matrix is a $2 \times 2$ lower triangular matrix representing the intercepts in the volatility model.

Asymmetries are captured by adding the term $\mathrm{D}^{\prime} v_{t-1} v_{t-1}^{t} \mathrm{D}$ to the conventional BEKK model where $v_{t-1}=u_{t-1} o I_{u<0}\left(u_{t-1}\right)$ and $o$ is the hadamard product of the vectors. We assume normally distributed statistical innovations which lead to the log likelihood function in (equation 3) that is maximized with respect to the parameter matrices A, B, C, and D. Allowing for asymmetry in our model provides valuable information to policy makers and economic agents participating in the marketing chain, on the existing differences between the impact of negative and positive news on potatoes market price fluctuations. The fact that asymmetric effects are significant indicates potential 
misspecification if asymmetries are ignored. Before concluding this section, it is relevant to note that, in contrast to the theoretical models that rely on economic theory and require an important amount of data, time-series models are nonstructural models that identify empirical regularities in the data. Our results should not be interpreted beyond this point.

\section{Empirical results}

The empirical application aims at assessing the links between weekly nominal consumer prices $\left(\mathrm{P}_{\mathrm{c}}\right)$ and wholesale prices $\left(\mathrm{P}_{\mathrm{w}}\right)$. Both prices are expressed in Egyptian pounds (L.E.) per kilo. The study period is from April 2011 to March 2014, yielding a total of 151 observations, obtained from (http://www.agriprice.gov.eg/). These prices correspond to national averages. The period of analysis is of interest, as it includes the first and second wave of the Egyptian revolution and is likely to reflect the impacts of the political and economic instability. Figure 1 shows the evolution of the two price series. RATS 8.0 software is used to carry out the estimation of the model. Logarithmic transformations of the prices are used in the empirical analysis ${ }^{1}$. Logarithmic transformations allow obtaining well behaved error terms and facilitate the interpretation of research results (5). The two series were tested for unit roots using standard unit root test according to $(7,20,29)$ and the tests confirm that the two series have a unit root. Descriptive statistics and unit root results of the prices are presented in table 1 .

Table 1. Descriptive statistics for weekly prices

(April 2011 to March 2014)

\begin{tabular}{|c|c|c|}
\hline & $\begin{array}{c}\text { Consumer } \\
\text { price }\end{array}$ & Wholesale price \\
\hline Mean (L.E. per Kilo) & 3.106 & 2.108 \\
\hline Standard deviation & 1.086 & 0.734 \\
\hline Maximum & 6.034 & 0.9 \\
\hline Minimum & 1.609 & 4.0 \\
\hline Skewness & $1.110^{* *}$ & 0.219 \\
\hline Kurtosis & $0.892^{* *}$ & -0.559 \\
\hline Jarque-Bera & $36.997 * *$ & 3.268 \\
\hline ADF & -2.446 & -2.744 \\
\hline Perron & -3.805 & -3.214 \\
\hline KPSS & $0.292^{* *}$ & $0.351 * *$ \\
\hline
\end{tabular}

$* * *(* *)[*]$ denotes statistical significance at the $1(5)[10] \%$ level

Note: the deterministic component used in conducting unit root tests is a constant

\footnotetext{
${ }^{1}$ By using logged prices, the parameters of the co-integrating vectors represent elasticities and the short-run dynamic parameters represent proportionate changes.
} 
Figure 1. Price series

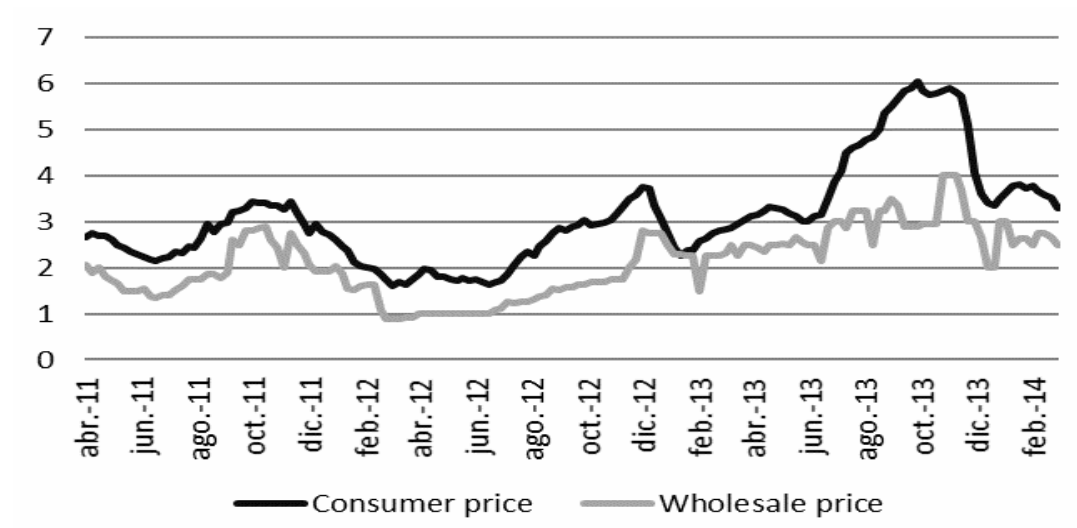

Long-run links between the two prices are assessed using the cointegration tests proposed by (17). Test results provide evidence that the prices considered are co-integrated with a co-integration rank $\mathrm{r}=1$, i.e., there is a single long-run relationship characterizing price behavior as shown in table 2 . The cointegration relationship presented in table 2 shows that the increase in wholesale prices has a high positive impact on consumer prices with price elasticity of 0.917, Co-integration parameters (table 2) suggest that, in the long-run, an increase in the wholesale prices will lead to an increase in consumer prices of potatoes. The high price elasticity could be attributed to the geographical proximity of the two markets which will incur lower transaction costs that facilitates price transmission along the food marketing chain. Engle and Granger (9) test for co-integration, taking consumer prices of potatoes as the endogenous variable in the price system, also support the existence of a long-run relationship characterizing the potatoes market. Hansen and Johansen (13) recursively calculated beta test for the null of constancy of the co-integration parameters shows that no structural breaks affect the co-integration relationship (figure 2).

Results from the one-step estimation of the VECM, the conditional mean model, and the multivariate asymmetric BEKK-GARCH, the conditional covariance model, are presented in tables 2 and 3, respectively. For ease of interpretation of MGARCH model, table 4 containing the nonlinear parameter functions of the conditional variance equations is presented. In the following lines, we focus on interpreting the conditional mean model. Consumer short-run price dynamics involve that current change in potatoes consumer prices are positively related to own past changes and wholesale lagged price changes. Short-run wholesale price dynamics are driven only by own lagged price changes. The wholesale and retail prices are found to respond to deviations from the long-run disequilibrium. i.e., both prices levels exert a relevant influence on one another to reach the long-run equilibrium. Results also indicate that wholesale prices respond to market deviations faster than consumer prices to maintain equilibrium. 
Residuals of the VECM were tested for multivariate autocorrelation following (15) variant of the multivariate $Q$ statistic and results led to accept the null of no autocorrelation. Also, the multivariate ARCH LM test was conducted and evidence of ARCH effects was found, thus supporting the use of a MGARCH model. We now turn to the interpretation of the conditional volatility model. The test for the null hypothesis that parameters in matrices A, B and D in the MGARCH model are equal to zero is rejected, showing evidence of time varying volatility, additionally, an LR test for the null that parameters in D matrix in the GARCH specification are zero is conducted to test for the relevance of the asymmetric effects. Results show that asymmetric effects are statistically significant (table 3). A fluctuations test following (28) was adopted and the result leads to accept the null of model stability.

Table 2. Consumer price - Wholesale price: conditional mean equations

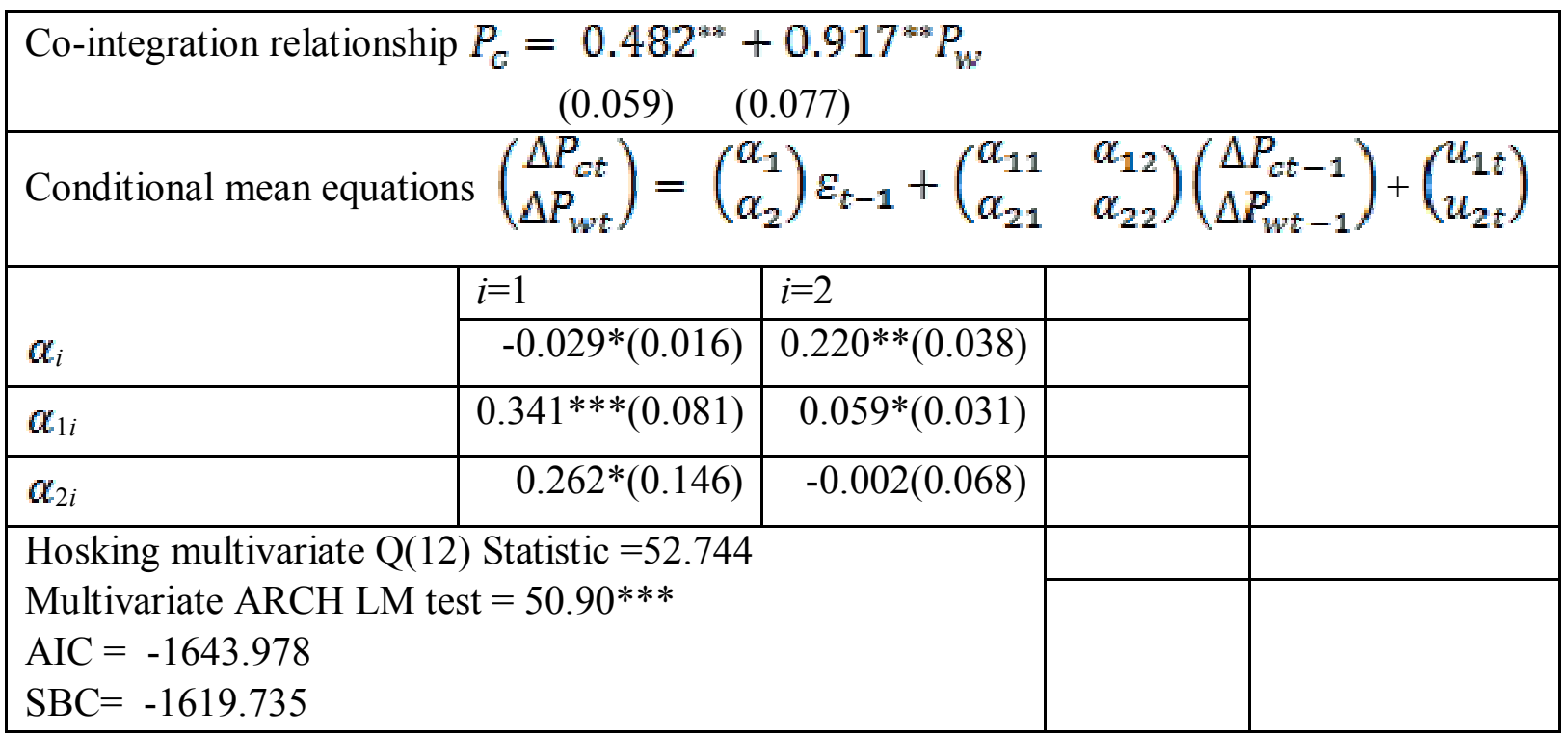

$P_{c}$ the Consumer price, $P_{w}$ the wholesale price

$* * *(* *)[*]$ denotes statistical significance at the 1 (5) [10] \% level

Standard errors in parenthesis

Figure 2. Test for cointegration parameter stability

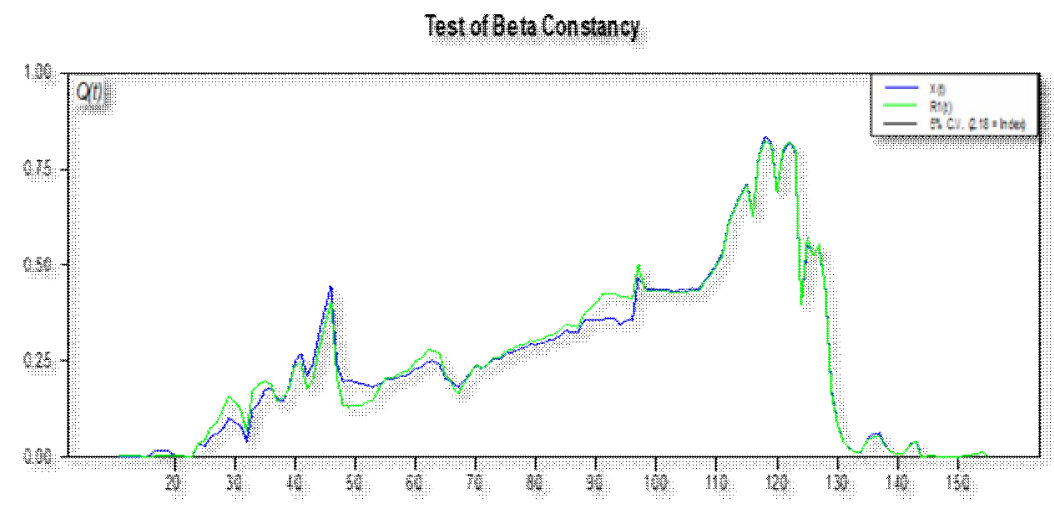

Note: the statistic is scaled by its $5 \%$ critical value 
Table 3. Consumer price - Wholesale price: conditional variance equations

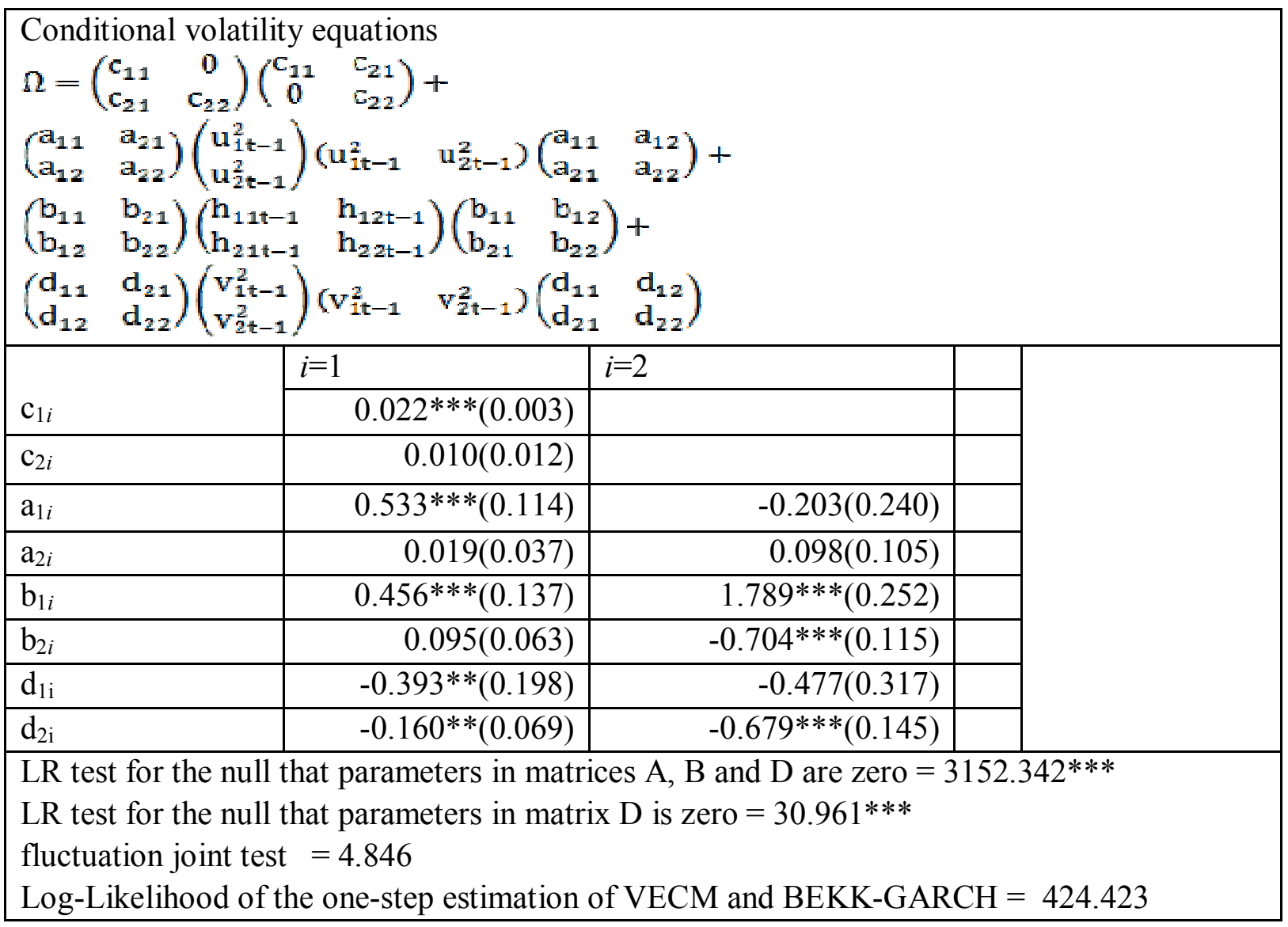

$* * *(* *)[*]$ denotes statistical significance at the 1 (5) [10] \% level

\section{Standard errors in parenthesis}

As noted above, individual coefficients of the MGARCH parameterization cannot be directly interpreted. Instead, we draw conclusions from the nonlinear parameter functions in the conditional variance equations (table 4). Results suggest statistically significant own past volatility $\left(\mathrm{h}_{11 \mathrm{t}-1}\right)$, past market shocks $\left(u_{1 t-1}^{2}\right)$ cause an increase on consumer price volatility $\left(h_{11 t}\right)$. Indirect past shocks to the wholesale price are found to have an asymmetric effect $\left(v_{12 t-1}^{2}\right)$ on consumer price volatility $\left(\mathrm{h}_{11 \mathrm{t}}\right)$, with negative price shocks increasing the consumer price variance more than price increases. The wholesale price volatility $\left(h_{22 t}\right)$ is affected by its own lagged volatility $\left(h_{22 t-1}\right)$, lagged consumer price volatility $\left(h_{11 t-1}\right)$ and indirect volatility spillovers $\left(h_{12 t-1}\right)$. The parameter representing $\left(\mathrm{h}_{12 \mathrm{t}-1}\right)$ indicates that the strength of the correlation between wholesale and consumer price volatility has an impact on wholesale price instability. While a positive and strong correlation will reduce instability, a negative strong correlation will enhance it. As the results show, stability is can be achieved when both prices move together in the same direction. To conclude, the results show that there is interaction between the consumer and wholesale markets on both prices levels and volatility and asymmetry was found to be 
relevant. The MGARCH model forecasts of the consumer and wholesale prices volatilities presented in (figures 3 and 4), respectively. The model predicts specially high volatility during 2011 and 2013 where it corresponds to the first and second waves of the Egyptian revolution which has led to an economic recession and to increased volatility in food prices in Egypt (33).

Table 4. Consumer price - Wholesale price: Conditional variance equations

$$
\begin{gathered}
\mathrm{h}_{11}=5.620 \mathrm{e}-04+0.210^{*} \mathrm{~h}_{11 \mathrm{t}-1}+0.010 \mathrm{~h}_{22 \mathrm{t}-1}+0.088 \mathrm{~h}_{12 \mathrm{t}-1} \\
+0.283^{* *} \mathrm{u}_{1 \mathrm{t}-1}^{2}+3.650 \mathrm{e}-04 \mathrm{u}_{2 \mathrm{t}-1}^{2}+0.020 \mathrm{u}_{12 \mathrm{t}-1} \\
+0.155 \mathrm{v}_{1 \mathrm{t}-1}^{2}+0.026 \mathrm{v}_{2 \mathrm{t}-1}^{2}+0.126^{* *} \mathrm{v}_{12 \mathrm{t}-1} \\
\mathrm{~h}_{22}=0.000+3.201^{* * *} \mathrm{~h}_{11 \mathrm{t}-1}+0.495^{* * *} \mathrm{~h}_{22 \mathrm{t}-1}-2.519^{* * *} \mathrm{~h}_{12 \mathrm{t}-1} \\
+0.041 \mathrm{u}_{1 \mathrm{t}-1}^{2}+0.010 \mathrm{u}_{2 \mathrm{t}-1}^{2}-0.040 \mathrm{u}_{12 \mathrm{t}-1}+0.227 \mathrm{v}_{1 \mathrm{t}-1}^{2} \\
+0.462^{* *} \mathrm{v}_{2 \mathrm{t}-1}^{2}-0.648 \mathrm{v}_{12 \mathrm{t}-1}
\end{gathered}
$$

$h_{11}$ consumer price conditional variance, $h_{22}$ wholesale price conditional variance. The standard errors of the estimated parameters are obtained using first order Taylor series expansion around its mean (delta method)

$* * *(* *)[*]$ denotes statistical significance at the $1(5)[10] \%$ level

Figure 2. Predicted volatility of consumer prices

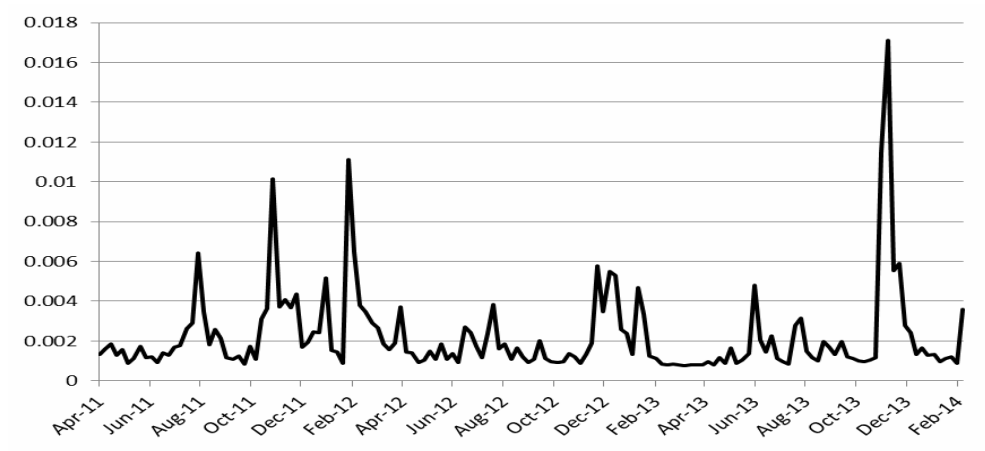

Figure 3. Predicted volatility of wholesale prices

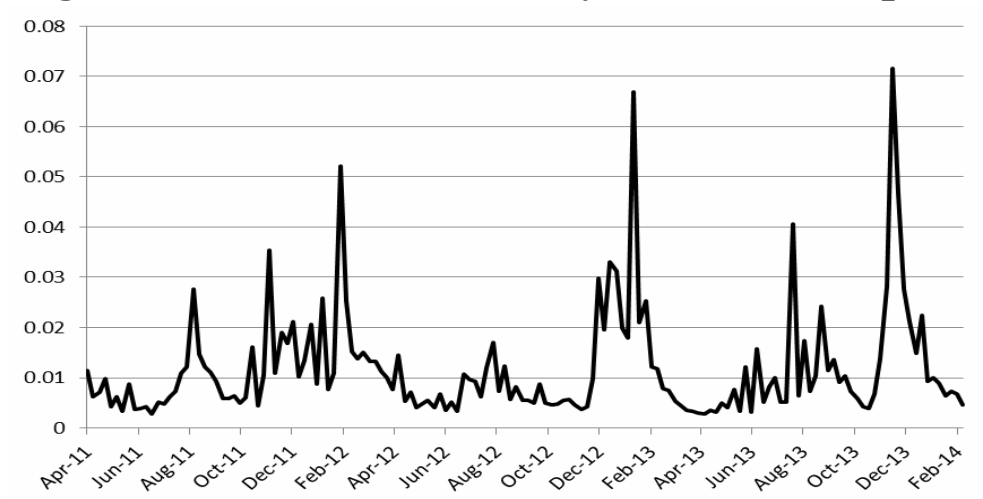




\section{Concluding remarks}

This paper investigates vertical price relationships in the Egyptian potatoes supply chain. We assess both price level links and asymmetric volatility interactions. Two prices are considered in the analysis; the consumer price and the wholesale price. Prices are observed at a weekly frequency from April 2011 to March 2014. Price level relationships are studied by means of a VECM model and volatility behavior is analyzed using asymmetric BEKK-GARCH model, the conditional mean and variance are estimated in one step using ML estimation. Our work is the first in assessing asymmetries in food price volatility, as well as in studying volatility spillovers in the Egyptian potatoes market.

We find consumer and wholesale prices to be interrelated in the long-run by an equilibrium parity. This parity is preserved by the downstream level of the potatoes supply chain in order to be in equilibrium. Statistically significant short-run price interactions are also found to characterize price dynamics. Wholesale prices are found to influence consumer prices in the long-run and the short-run. The wholesale prices are found to respond to market disequilibrium faster than retail prices. Significant volatility spillovers between the wholesale and the retail levels are found to be relevant with strong volatility spillovers from the retail market to the wholesale market. Evidence of direct and indirect asymmetries in price volatility patterns is also found, with negative shocks causing more price instability than positive ones. The results of this study provide information to policy makers on which market causes more volatility and that negative shocks have a stronger effect on volatility than positive ones. This information could help policymakers understand how to apply new policies like increase access to agricultural information systems, improve the functionality of the potatoes markets and reduce transaction costs in order to minimize markets risks which is common in concentrated value chains.

\section{References}

(1) Ahmed, O., \& Serra, T. (2014). Price volatility of food staples. The case of millet in Niger. Paper presented at the 14th European Association of Agricultural Economists (EAAE) Conference, Ljubljana, Slovenia, August 26-29, 2014.

(2) Alhashim, J., \& Saghaian, S. (2015). Price Transmission Analysis in the Fresh Vegetable Supply Chain of Saudi Arabia. Selected Paper prepared for presentation at the Southern Agricultural Economics Association (SAEA) Annual Meetings, Atlanta, Georgia: February 1-4, 2015. 
(3) Assefa, T.T., Meuwissen, M.P.M., Oude Lansinkm A.G.J.M., 2013. Literature review on Price volatility transmission on food supply chain, the role of contextual factors, and the CAP's market measures. Working paper. ULYSSES "Understanding and coping with food markets volatility towards more Stable World and EU food Systems".

(4) Baquedano, F., \& liefert, W. (2014). Market integration and price transmission in consumer markets of developing countries. Food Policy, 44: 103-114.

(5) Bierlen, R., Wailes, E.J., Cramer, G.L., 1998. Unilateral reforms, trade blocs, and law of one price. Agribusiness. 14,183-198.

(6) Deaton, A., \& Laroque, G. (1992). On the behavior of commodity prices. Review of Economic Studies, 59:1-23.

(7) Dickey, D., \& Fuller, W. (1979). Distribution of the estimators for autoregressive time series with a unit root. Journal American Statistical Association, 74:427-431.

(8) Engle, R.F., \& Kroner, K.F. (1995). Multivariate simultaneous generalized ARCH. Econometric Theory, 11:122-150.

(9) Engle, R.F., \& Granger, C.W.J. (1987). Co-integration and error correction: representation, estimation, and testing. Econometrica, 55:251-276.

(10) Frey, J., \& Manera, M. (2007). Econometric Models of Asymmetric Price Transmission. Journal of Economic Surveys, 21:449-415.

(11) Food and Agriculture Organization of the United Nations, Statistics Division. (FAOSTAT, 2015). Country profile. Available at: http://faostat.fao.org/CountryProfiles/Country_Profile/Direct.aspx?lang=e $\underline{n} \& a r e a=59$ (Last accessed September 2014).

(12) Goodwin, B.K., \& Holt, M.T. (1999). Price transmission and asymmetric adjustment in the U.S. beef sector. American Journal Agricultural Economics, 81:630-637.

(13) Hansen, H., \& Johansen, S. (1999). Some tests for parameter constancy in cointegrated VAR-models. Journal of Business and Economic Statistics, 19:166-176.

(14) Hassouneh, I., Radwan, A., Serra T. and Gil J.M. (2012). Food Scare Crises and Developing Countries: The Impact of Avian Influenza on Vertical Price Transmission in the Egyptian Poultry Sector. Food Policy, 37: 264274. 
(15) Hosking, J.R.M. (1981). Equivalent Forms of the Multivariate Portmanteau Statistic. Journal of Royal Statistical Society, series B. 43:261-262.

(16) International Food Policy Research Institute and World Food Program (IFPRI-WFP), (2013). Tackling Egypt's Rising Food Insecurity in a Time of Transition. Joint IFPRI-WFP country policy note. Available at: http://www.ifpri.org/sites/default/files/publications/ifpriwfppn_egypt.pdf

(17) Johansen, S. (1988). Statistical analysis of cointegration vectors. Journal of Economic Dynamics and Control, 12:231-254.

(18) Kornher, L., Kalkuhl, M., (2013). Food price volatility in developing countries and its determinants. Quarterly Journal of International Agriculture, 52:277-308

(19) Kroner, K.F., \& Ng, V.K. (1998). Modeling asymmetric comovements of asset returns. Review Financial Studies, 11:817-844.

(20) Kwiatkowski, D., Phillips, P.C.B., Schmidt, P., \& Shin, Y. (1992). Testing the null hypothesis of stationarity against the alternative of a unit root: How sure are we that economic time series have a unit root? Journal of Econometrics, 54:159-178.

(21) Minot, N. (2010). Transmission of World Food Price Changes to African Markets and Its Effect on Household Welfare. IFPRI Discussion Paper 1059. Washington, DC: International Food Policy Research Institute

(22) Minot, N. (2014). Food price volatility in sub-Saharan Africa: Has it really increased? Food Policy, 45:45-56.

(23) Mkhabela, T., \& Nyhodo, B. (2011). Farm and Retail Prices in the South African Poultry Industry: A Do the Twain Meet? International food and Agribusiness Management Review. 14:127-146.

(24) Meyer, J., \& Cramon-Taubadel, S.v. (2004). Asymmetric price transmission: A Survey. Journal of Agricultural Economics, 55:581-611.

(25) Mofya-Mukuka, R., \& Abdulai, A. (2013). Effects of Policy Reforms on Price Transmission in Coffee Markets: Evidence from Zambia and Tanzania. Economic Modeling, 35:786-795.

(26) Myers, R.J. (1994). Time series econometrics and commodity price analysis: A Review. Review of Marketing and Agricultural Economics, 62:167-181. 
(27) Norton, R. (2004). Agricultural development policy. Concepts and experiences: Concepts and experiences. Food and Agricultural Organization of the United Nations - FAO. Rome.

(28) Nyblom, J. (1989). Testing for the constancy of parameters over Time. Journal of American Statistical Association, 84:223-230.

(29) Perron, P. (1997). Further evidence on breaking trend functions in macroeconomic variables. Journal of Econometrics, 80:355-385.

(30) Prakash, A., \& Gilbert, L.C. (2011). Rising vulnerability in global food system: beyond market fundamentals. In: A. Prakash (ed.), Safeguarding Food Security in Volatile Global Markets. Rome: FAO, 111-125.

(31) Uchezuba, I.D., Jooste, A., \& Willemse, J. (2010). Measuring Asymmetric Price and Volatility Spillover in the South African Broiler Market. AAAE Third Conference/AEASA 48th Conference, September 19-23, Cape Town, South Africa. Accessed Sep. 2013.

(32) United Nations Commodity Trade Statistics (Comtrade, 2015). Available at: http://comtrade.un.org/data/ (Last accessed January 2014).

(33) USAID, 2002. Assessment of Egypt's Agricultural Sector Competitiveness, Volume II: Analysis, Principal Findings, and Recommendations. Available at: http://pdf.usaid.gov/pdf_docs/ Pnadd576.pdf (Last accessed September 2015).

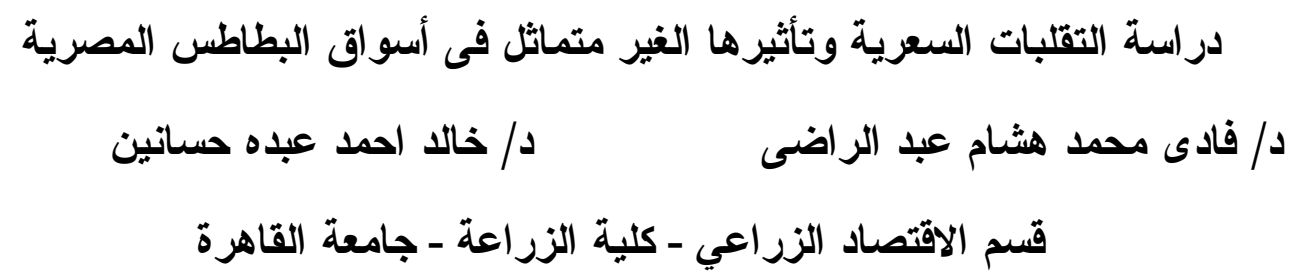

الماخص

يهتم هذا البحث بدراسة العلاقة الأفقية لأسعار محصول البطاطس علي مستوي سوقي الجملة و التجزئة، كما نم دراسة العلاقة بين المستوي السعري و كذلك عدم الاستقرار السعري في كلا

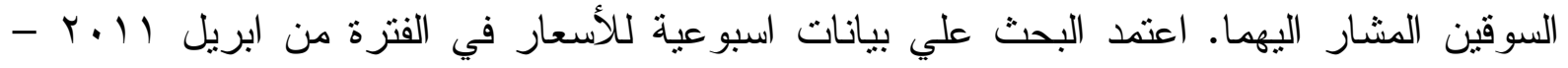
مارس عـ ا.ب. تم قياس العلاقة بين المستوي السعري لأسعار البطاطس في سوقي الجملة والتجزئة باستخدام نموذج Vector Error Correction Model أما عدم الاستقرار السعري بين السوقين فتم 
قياسه باستخدام نموذج Asymmetric BEKK GARCH وتم حساب كلا النموذجين في خطوة واحدة اعتمادا علي طريقة الحساب Maximum Likelihood.

اظهرت النتائج ارتباط كلا من اسعار المستهلكين واسعار الجملة علي المدي الطويل بشكل متوازن ويستمد هذا النوازن من اسواق التجزئة. كما أظهرت النتائج وجود اثر معنوي في الثعار الدئي

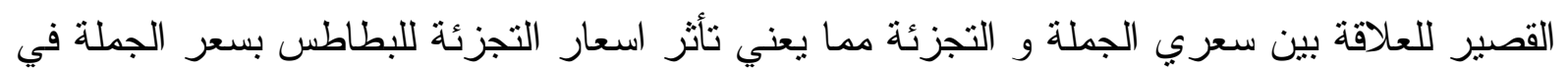

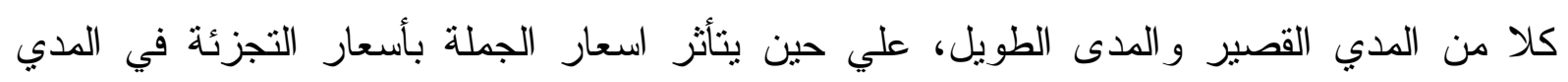

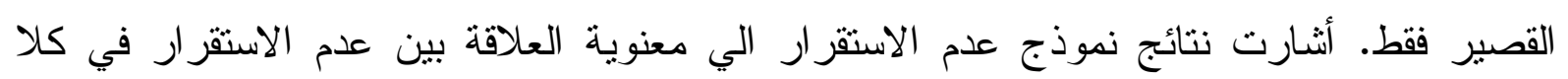

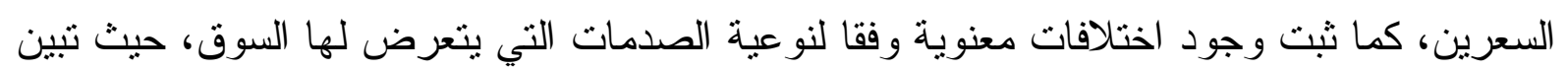
ان الصدمات السعرية السالبة نؤثر بدرجة اعلي مقارنة بالصدمات السعرية الموجبة. 